\title{
STORAGE STUDIES ON BITTER GOURD JUICE PRESERVED WITH DIFFERENT CHEMICAL PRESERVATIVES
}

\author{
Gurpreet Kaur $^{1}$, Poonam Aggarwal ${ }^{2}$ \\ ${ }^{I}$ PhD Scholar, ${ }^{2}$ Senior Vegetable Technologist, Department of Food Science and Technology Punjab Agricultural \\ University, Ludhiana, Punjab, India
}

\begin{abstract}
Bitter gourd (Momordica charantia) is one of the most popular vegetables in Southeast Asia. It is a member of the cucurbit family and is also known as bitter melon or balsam pear. It is a good source of ascorbic acid and is used in the treatment of infectious diseases. It is anti-diabetic, stimulant, stomachic, laxative, blood purifier and control diabetes. This seasonal vegetable can be made available for the consumers in off seasons also in the form of juice. The juice can be made shelf stable by using various chemical additives. Therefore, the aim of the experiment was to compare the effect of different chemical additives namely Sodium benzoate, Potassium metabisulfite (KMS) and their combination, on the physicochemical and phytochemical parameters and antioxidant activity of Bitter gourd juice. The storage was done for 6 months at room temperature and the analysis was conducted at the interval of one month. For the physicochemical parameters like TS, TSS, acidity and Total Phenols, very slight but non-significant change was observed. Color values (Lab), Vitamin $C$ and antioxidant activity changed significantly ( $p \leq 0.05)$. The variation was found in the color of different samples. Considering all the parameters, samples treated with potassium metabisulfite (KMS) maintained the maximum nutrient stability.
\end{abstract}

Keywords: Antioxidant activity, Chemical additives, Bitter gourd, Phytochemicals

\section{INTRODUCTION}

Bitter gourd is one of the most popular vegetables in Southeast Asia. It is a member of the cucurbit family along with cucumber, squash, watermelon and muskmelon. Native to China or India, the fast growing vine is grown throughout Asia and is becoming popular worldwide. Depending on location, bitter gourd is also known as bitter melon or balsam pear [1]. The vegetable is a good source of ascorbic acid [2]. The medicinal value of bitter gourd in the treatment of infectious diseases and diabetes is attracting the attention of scientists worldwide. Bitter gourd is anti-diabetic, stimulant, stomachic, laxative, blood purifier and control diabetes [3]. As it is a seasonal vegetable, so steps should be taken to preserve them to make them available for consumption in off season as well. This could be achieved by extending the shelf life in fresh form or in the processed form [4]. Much of the work is done for preservation of bitter gourd by different methods such as steeping preservation, processing of bitter gourd into rings [5], sun drying and dehydration of bitter gourd [6], hot air drying of bitter gourd slices[7]etc. But the excellent medicinal virtues of bitter gourd can benefit the consumers equally in the form of juice also. However, information on the processing of bitter gourd into juice and its preservation by chemical additives is scanty. Keeping this in view, the current study was focused on assessing the effect of different preservation methods on the shelf stability of the processed Bitter gourd juice.

\section{MATERIALS AND METHODS}

\subsection{Raw Materials}

The study was conducted in the Department of Food Science and Technology, Punjab Agricultural University, Ludhiana. Bitter gourd was procured from the local market.

\subsection{Extraction Process of Bitter Gourd Juice}

Fresh bitter gourds were washed thoroughly and cut off from the top and were not peeled. The Bitter gourd juice was extracted in a juicer extractor (Kalsi: 9001-2008). The juice was pasteurized at $83^{\circ} \mathrm{C}$ for $3 \mathrm{~min}$ and citric acid @ $0.15 \%$ was added, followed by chemical preservatives.

Dose distribution of chemical additives

\begin{tabular}{|c|c|c|}
\hline Sample & Chemical additives & Dose(ppm) \\
\hline $\mathrm{T}_{2}$ & Na-benzoate & 3000 \\
\hline $\mathrm{T}_{3}$ & KMS & 3000 \\
\hline $\mathrm{T}_{4}$ & Na-benzoate+ KMS & $1500+1500$ \\
\hline
\end{tabular}

The pre-sterilized glass bottles were filled with the hot juice and corked. $\mathrm{T}_{1}$ sample was given the pasteurization treatment followed by processing at $100^{\circ} \mathrm{C}$ for $20 \mathrm{~min}$ in boiling water bath and gradually cooled to a low temperature under running 
tap water. These processed juices were kept for storage at room temperature for six months.

\subsection{Physico-Chemical Analysis}

Bitter gourd juices were analyzed at regular interval of one month for the parameters like Total solids, Titratable acidity using AOAC methods [8]. TSS was taken using hand refractometer(ERMA, Japan), color using Minolta Hunter colorimeter.

\subsection{Phytochemical Analysis}

For phytochemical parameters, Vitamin $\mathrm{C}$ was determined by the titrimetric method using dichlorophenol indophenol dye [9]. Total phenolic content was determined by Folinciocalteau reagent [10]. A standard curve was plotted by taking known amount of Gallic acid as reference standard and concentration was calculated from the standard curve. The \% Antioxidant activity was determined by DPPH (2, 2-diphenyl2-picrylhydrazyl) method [11]. Methanolic extract of sample was taken for antioxidant activity analysis and calculated according to the following formula. BHT was taken as a standard at a fixed concentration of $5 \mathrm{mg} / \mathrm{ml}$.

\section{$\% \mathrm{AA}=$ Control OD $(0 \mathrm{~min})-$ Sample OD $(30 \mathrm{~min}) \times 100$ Control OD (0 min)}

\subsection{Statistical Analysis}

The results were evaluated by Analysis of Variance (ANOVA) and Tukey's post hoc tests using Systat statistical program version 16 (SPSS Inc., USA).

\section{RESULTS AND DISCUSSION}

The samples were studied for the effect of different chemical additives on Physicochemical [TS, TSS, Acidity, Color (L, a, b)], Phytochemical (Ascorbic acid, Total phenols) and \% antioxidant activity for the storage period of 6 months.

\subsection{Effect on Total Solids and TSS}

TS increased non-significantly $(\mathrm{p} \leq 0.05)$ in all the juices during the storage. On the day of preparation, the amount of TS in sample T1, T2, T3, T4 were 12.01, 12.60, 12.16 and 12.73 respectively. At the end of 6 months, the TS in the samples increased to $13.37,13.19,12.86$ and 13.54 respectively. The TSS values of samples T1 to T4 on day first were 3.2, 3.3, 3.4 and 3.3 which gradually increased to $3.4,3.5,3.6$ and 3.5 respectively after 6 months of storage. Although TSS increased for all the samples but the changes were nonsignificant $(\mathrm{p} \leq 0.05)$. An increase in soluble content of apple pulp was reported during storage when preserved with chemical preservatives [12]. The treatments had no significant effect $(\mathrm{p} \leq 0.05)$ on Total solids as well as TSS.

\subsection{Effect on Acidity}

According to the results, chemical additives as well as storage has no significant effect $(\mathrm{p} \leq 0.05)$ on acidity of the bitter gourd juice. The titratable acidity of samples $T_{1}$ to $T_{4}$ on day first was found to be $0.0440 .038,0.038$ and 0.051 that gradually increased to $0.067,0.057,0.041$ and 0.061 respectively (Table 1). An increase in titratable acidity of apple pulp was found during storage [12]. The acidity of the thermally treated sample $\left(T_{1}\right)$ increased more as compared to other chemically treated samples and the change was least in $\mathrm{T}_{3}$ sample.

\subsection{Effect on Color ( $L$ a b values)}

The values for color varied significantly $(\mathrm{p} \leq 0.05)$, both for storage as well as chemical treatments. On the day of preparation, the lightest sample was $T_{1}$ followed by $T_{3}, T_{4}$ and $T_{2}$. At the end of 6 months, $T_{3}$ remained the lightest and $T_{2}$ was found to be darker than the other samples. Although, the ' $a$ ' value changed non-significantly $(\mathrm{p} \leq 0.05)$, but in terms of greenness, $T_{2}$ was found to be the greenest and retained the maximum greenness than the other 3 samples at the end of 6 months (Table 2). The $b$ values were highest for $T_{1}$ and lowest for $T_{3}$ and results after 6 months of storage, remained the same for all the samples. On the whole, sample $\mathrm{T}_{2}$ with Sodium benzoate retained the best color of all the 4 samples. Tomato juice with $\mathrm{Na}$ benzoate seems to be more stable than the other preservatives during 6 months of storage and developed lesser off color and turbidity [13].

\subsection{Effect on Vitamin C Content}

According to the results, chemical additives have significant effect $(\mathrm{p} \leq 0.05)$ on Vitamin $\mathrm{C}$ content of bitter gourd juice. Also the Vitamin $C$ content decreased significantly $(\mathrm{p} \leq 0.05)$ during the storage. On the day of preparation, Vitamin $\mathrm{C}$ content in samples $\mathrm{T}_{1}, \mathrm{~T}_{2}, \mathrm{~T}_{3}$ and $\mathrm{T}_{4}$ was $24.99,33.32,34.03$ and $36.65 \mathrm{mg} / 100 \mathrm{~g}$ respectively. The values came out to be lower in $\mathrm{T}_{1}$ as heat treatment destroys Vitamin $\mathrm{C}$. At the end of 6 months, the Vitamin C content reduced to 11.97, 15.69, 18.21 and 17.74 respectively (Table 3). Vitamin $\mathrm{C}$ is light and heat sensitive, the concentration of Vitamin $\mathrm{C}$ follows first order kinetics and thus storage time affects Vitamin $\mathrm{C}$ content [14]. Out of the chemically treated samples, potassium metabisulphite retained the maximum Vitamin $C$. The application of KMS reduces the loss of ascorbic acid during the storage of leafy vegetables [15].

\subsection{Effect on Total Phenols}

The total phenolic content in samples $\mathrm{T}_{1}$ to $\mathrm{T}_{4}$ on the first day was $60,70,84$, and 78 respectively. The added chemicals preserved the phenolic content more than thermally treated sample $\left(\mathrm{T}_{1}\right)$. But both the treatments and storage affected the total phenols non-significantly $(\mathrm{p} \leq 0.05)$. At the end of 6 months, the Total phenolic content came out to be $28,40,54$ 
and 48 respectively (Table 4). According to the findings, a decrease in total polyphenol content of tomato juices after 3,6 and 9 months of storage were reported [16]. The decrease was found to be least in sample $T_{3}$, followed by $T_{4}$ and $T_{2}$.

\subsection{Effect on Antioxidant Activity}

According to the results, on the day of preparation, percent Antioxidant activity for samples $T_{1}$ to $T_{4}$ was found to be $69.17,50.33,73.76$ and 64.13 respectively (Table 5). Significant $(\mathrm{p} \leq 0.05)$ decrease in antioxidant activity was found in treatments and also during storage months. At the end of 6 months, the percent antioxidant activity decreased to $78.37,75.89,84.35$ and 78.83 percent respectively. However, the decrease was found to be least in sample $\mathrm{T}_{3}$. It has been reported that the decrease in antioxidant activity may be linked to a decrease in total phenolic content and vitamin $\mathrm{C}$ during storage [17]. According to them, antioxidant activity of orange juices decreased by 45 percent after 6 months of storage at $28^{\circ} \mathrm{C}$. But in case of bitter gourd, the vitamin content is relatively high. So the reduction of antioxidant activity is mainly associated with significant decrease in vitamin content.

\section{CONCLUSIONS}

The experiment was to compare the effect of different chemical additives on the storage stability of bitter gourd juice. In this study, it is evident that potassium metabisulphite proved to be a better preservative than Na-benzoate and their combination for the stability of physicochemical and phytochemical parameters and maintaining the antioxidant activity of the bottle gourd juice.

\section{REFERENCES}

[1]. Satkar KP, Kulthe AA, Chalke PR (2013) Preparation of bitter gourd ready-to-serve beverage and effect of storage temperature on its keeping quality. The Bioscan 8: 115-117.

[2]. Kalra CL, Berry SK, Kulkarni SG (1988) The bitter gourd - A unique vegetable. Ind Food Pack. 42: 35-45.

[3]. Raman A, Lau C (1996) Anti-diabetic properties and Phytomed 2: phytochemistry of Memordica charantia L. (Cucurbitaceae). 349-362.
[4]. Deore PM, Kotecha PM, Pawar VD (2008) Studies on Processing of Bottle gourd into Juice and powder. J Food Pack 30: 116-120.

[5]. Kalra CL, Pruthi JS, Teotia MS, Raina BN (1983) Influence of variety on the quality of processed bitter gourd. Ind Food Pack 37: 71-77.

[6]. Raman S, Manimegalai G (1998) Effect of pretreatments on the quality characteristics of dehydrated bitter gourd rings. Ind Food Pack 52 :7-14.

[7]. Lidhoo CK (2007) Hot air drying characteristic of bitter gourd slices. Ind Food Pack 61: 79-80.

[8]. AOAC (2000) Official Methods of Analysis. 17th ed. Association of official Analytical Chemists, Washington. DC.

[9]. Ranganna S (1986) Handbook of Analysis and Quality Control for Fruit and Vegetable Product. Tata McGraw Hill Pub Co. Ltd., New Delhi, India.

[10]. Singleton VL, Rossi JA (1965) Colorimetry of total phenolics with phosphomolybdic-phosphotungstic acid reagents. Amer J Enol Viticul 16: 144-53.

[11]. Brand-Williams W, Cuvelier ME, Berset C(1995) Use of a free radical method to evaluate antioxidant activity. LWTFood Sci Technol. 28: 25-30.

[12]. Kinh SAEH, Dunne CP, Hoover DG (2001) Preparation and preservation of apple pulp with chemical preservatives and mild heat. J Food Protect 28: 111-114.

[13]. Hossain MN, Fakruddin M, Islam MN (2011) Effect of Chemical additives on the shelf life of Tomato juice. Amer $\mathbf{J}$ Food Technol. 6: 914-923.

[14]. Heldman DR, Singh RP (1981) Food Process Engineering. AVI Publishing Co., New York.

[15]. Negi PS, Roy K (2000) Effect of blanching and drying method on carotene, ascorbic acid and chlorophyll retention of leafy vegetable. LWT- Food Sci Technol. 33: 295-298.

[16]. Vallverdu-Queralt A, Arranz S, Medina-Remon A, Casals-Ribes I, Lamuela- Raventos RM (2011) Changes in phenolic content of tomato products during storage. J Agric Food Chem. 59: 9359-9365.

[17]. Klimczak I, Matecka M, Szlachta M, GliszczynskaSwiglo A (2007) Effect of storage on the content of polyphenols, Vitamin $\mathrm{C}$ and the antioxidant activity of orange juices. J Food Compos Anal. 20: 313-22.

Table 1: Effect of storage period and treatments on Titratable acidity (\%) of Bitter gourd juice

\begin{tabular}{|c|c|c|c|c|c|c|c|}
\hline Treatments & 0 & 1 & 2 & 3 & 4 & 5 & 6 \\
\hline $\mathrm{T} 1$ & $0.044^{\mathrm{aA}}$ & $0.048^{\mathrm{aA}}$ & $0.051^{\mathrm{aA}}$ & $0.054^{\mathrm{aA}}$ & $0.059^{\mathrm{aA}}$ & $0.062^{\mathrm{aA}}$ & $0.067^{\mathrm{aA}}$ \\
\hline $\mathrm{T} 2$ & $0.038^{\mathrm{aA}}$ & $0.039^{\mathrm{aA}}$ & $0.043^{\mathrm{aA}}$ & $0.046^{\mathrm{aA}}$ & $0.049^{\mathrm{aA}}$ & $0.052^{\mathrm{aA}}$ & $0.057^{\mathrm{aA}}$ \\
\hline $\mathrm{T} 3$ & $0.038^{\mathrm{aA}}$ & $0.039^{\mathrm{aA}}$ & $0.042^{\mathrm{aA}}$ & $0.044^{\mathrm{aA}}$ & $0.047^{\mathrm{aA}}$ & $0.049^{\mathrm{aA}}$ & $0.051^{\mathrm{aA}}$ \\
\hline $\mathrm{T} 4$ & $0.041^{\mathrm{aA}}$ & $0.042^{\mathrm{aA}}$ & $0.047^{\mathrm{aA}}$ & $0.051^{\mathrm{aA}}$ & $0.055^{\mathrm{aA}}$ & $0.058^{\mathrm{aA}}$ & $0.061^{\mathrm{aA}}$ \\
\hline
\end{tabular}

* Data is expressed as means

*Values followed by different upper case or lower case letters are significantly different $(\mathrm{p} \leq 0.05)$ within columns and rows respectively 
Table 2: Effect of storage period and treatments on the color values ( $\mathrm{L} \mathrm{a} \mathrm{b}$ ) of Bitter gourd juice

\begin{tabular}{|c|c|c|c|c|c|c|c|c|}
\hline \multicolumn{2}{|c|}{ Treatments } & 0 & 1 & 2 & 3 & 4 & 5 & 6 \\
\hline \multirow{4}{*}{$\mathbf{L}$} & $\mathrm{T} 1$ & $34.83^{\mathrm{aA}}$ & $34.43^{\mathrm{aA}}$ & $33.91^{\mathrm{aA}}$ & $33.75^{\mathrm{aA}}$ & $32.44^{\mathrm{aA}}$ & $31.64^{\mathrm{aA}}$ & $30.87^{\mathrm{aA}}$ \\
\hline & $\mathrm{T} 2$ & $32.61^{\mathrm{aC}}$ & $32.43^{\mathrm{aC}}$ & $32.31^{\mathrm{aC}}$ & $32.08^{\mathrm{aB}}$ & $31.65^{\mathrm{BCA}}$ & $31.19^{\mathrm{aB}}$ & $30.67^{\mathrm{aA}}$ \\
\hline & $\mathrm{T} 3$ & $33.81^{\mathrm{aB}}$ & $33.69^{\mathrm{aBC}}$ & $33.44^{\mathrm{aBC}}$ & $33.03^{\mathrm{aB}}$ & $32.71^{\mathrm{aC}}$ & $32.39^{\mathrm{aC}}$ & $31.83^{\mathrm{aB}}$ \\
\hline & $\mathrm{T} 4$ & $32.68^{\mathrm{Ab}}$ & $32.57^{\mathrm{aB}}$ & $32.39^{\mathrm{aB}}$ & $32.13^{\mathrm{aB}}$ & $31.81^{\mathrm{aB}}$ & $31.64^{\mathrm{aAB}}$ & $31.32^{\mathrm{aA}}$ \\
\hline \multirow{4}{*}{$\mathbf{a}$} & $\mathrm{T} 1$ & $-1.03^{\mathrm{aA}}$ & $-1.01^{\mathrm{aA}}$ & $-0.99^{\mathrm{aA}}$ & $-0.97^{\mathrm{aA}}$ & $-0.95^{\mathrm{aA}}$ & $-0.91^{\mathrm{aA}}$ & $-0.89^{\mathrm{aA}}$ \\
\hline & $\mathrm{T} 2$ & $-1.12^{\mathrm{aA}}$ & $-1.11^{\mathrm{aA}}$ & $-1.09^{\mathrm{aA}}$ & $-1.07^{\mathrm{aA}}$ & $-1.04^{\mathrm{aA}}$ & $-1.01^{\mathrm{aA}}$ & $-0.98^{\mathrm{aA}}$ \\
\hline & $\mathrm{T} 3$ & $-0.96^{\mathrm{aA}}$ & $-0.92^{\mathrm{aA}}$ & $-0.87^{\mathrm{aA}}$ & $-0.82^{\mathrm{aA}}$ & $-0.77^{\mathrm{aA}}$ & $-0.71^{\mathrm{aA}}$ & $-0.65^{\mathrm{aA}}$ \\
\hline & $\mathrm{T} 4$ & $-0.97^{\mathrm{aA}}$ & $-0.94^{\mathrm{aA}}$ & $-0.90^{\mathrm{aA}}$ & $-0.86^{\mathrm{aA}}$ & $-0.83^{\mathrm{aA}}$ & $-0.78^{\mathrm{aA}}$ & $-0.72^{\mathrm{aA}}$ \\
\hline \multirow{4}{*}{ b } & $\mathrm{T} 1$ & $4.6^{\mathrm{aA}}$ & $4.12^{\mathrm{abA}}$ & $3.84^{\mathrm{abA}}$ & $3.56^{\mathrm{bcA}}$ & $3.29^{\mathrm{bcA}}$ & $2.98^{\mathrm{cA}}$ & $2.76^{\mathrm{cA}}$ \\
\hline & $\mathrm{T} 2$ & $3.28^{\mathrm{aB}}$ & $3.08^{\mathrm{aB}}$ & $2.84^{\mathrm{abB}}$ & $2.65^{\mathrm{abcB}}$ & $2.23^{\mathrm{bcB}}$ & $2.09^{\mathrm{bcB}}$ & $1.89^{\mathrm{cB}}$ \\
\hline & $\mathrm{T} 3$ & $2.01^{\mathrm{aC}}$ & $1.98^{\mathrm{aC}}$ & $1.94^{\mathrm{aC}}$ & $1.85^{\mathrm{aB}}$ & $1.73^{\mathrm{aB}}$ & $1.61^{\mathrm{aB}}$ & $1.49^{\mathrm{aB}}$ \\
\hline & $\mathrm{T} 4$ & $2.14^{\mathrm{aC}}$ & $2.06^{\mathrm{aC}}$ & $1.97^{\mathrm{aC}}$ & $1.87^{\mathrm{aB}}$ & $1.75^{\mathrm{aB}}$ & $1.62^{\mathrm{aB}}$ & $1.54^{\mathrm{aB}}$ \\
\hline
\end{tabular}

* Data is expressed as means

*Values followed by different upper case or lower case letters are significantly different $(\mathrm{p} \leq 0.05)$ within columns and rows respectively

Table 3: Effect of storage period and treatments on Vitamin C content $(\mathrm{mg} / 100 \mathrm{~g})$ of Bitter gourd juice

\begin{tabular}{|c|c|c|c|c|c|c|c|}
\hline Treatments & 0 & 1 & 2 & 3 & 4 & 5 & 6 \\
\hline $\mathrm{T} 1$ & $24.99^{\mathrm{aB}}$ & $22.83^{\mathrm{abB}}$ & $19.72^{\mathrm{bcB}}$ & $17.65^{\mathrm{cdB}}$ & $15.77^{\mathrm{deB}}$ & $13.52^{\mathrm{efB}}$ & $11.97^{\mathrm{fB}}$ \\
\hline $\mathrm{T} 2$ & $33.32^{\mathrm{aA}}$ & $30.61^{\mathrm{abA}}$ & $27.74^{\mathrm{bcA}}$ & $24.53^{\mathrm{cdA}}$ & $22.42^{\mathrm{deA}}$ & $19.29^{\mathrm{efA}}$ & $15.69^{\mathrm{fA}}$ \\
\hline $\mathrm{T} 3$ & $34.03^{\mathrm{aA}}$ & $31.88^{\mathrm{abA}}$ & $28.56^{\mathrm{bcA}}$ & $25.77^{\mathrm{cdA}}$ & $23.23^{\mathrm{deA}}$ & $20.41^{\mathrm{efA}}$ & $18.21^{\mathrm{fA}}$ \\
\hline $\mathrm{T} 4$ & $36.65^{\mathrm{aA}}$ & $33.66^{\mathrm{abA}}$ & $30.16^{\mathrm{bcA}}$ & $27.02^{\mathrm{cdA}}$ & $24.92^{\mathrm{deA}}$ & $21.33^{\mathrm{efA}}$ & $17.74^{\mathrm{fA}}$ \\
\hline
\end{tabular}

* Data is expressed as means

*Values followed by different upper case or lower case letters are significantly different $(\mathrm{p} \leq 0.05)$ within columns and rows respectively

Table 4: Effect of storage period and treatments on Total Phenols (mg/100g) of Bitter gourd juice

\begin{tabular}{|c|c|c|c|c|c|c|c|}
\hline Treatments & 0 & 1 & 2 & 3 & 4 & 5 & 6 \\
\hline $\mathrm{T} 1$ & $60^{\mathrm{aA}}$ & $57^{\mathrm{aA}}$ & $53^{\mathrm{aA}}$ & $48^{\mathrm{aA}}$ & $42^{\mathrm{aA}}$ & $35^{\mathrm{aA}}$ & $28^{\mathrm{aA}}$ \\
\hline $\mathrm{T} 2$ & $70^{\mathrm{aA}}$ & $68^{\mathrm{aA}}$ & $65^{\mathrm{aA}}$ & $60^{\mathrm{aA}}$ & $55^{\mathrm{aA}}$ & $48^{\mathrm{aA}}$ & $60^{\mathrm{aA}}$ \\
\hline $\mathrm{T} 3$ & $84^{\mathrm{aA}}$ & $82^{\mathrm{aA}}$ & $78^{\mathrm{aA}}$ & $73^{\mathrm{aA}}$ & $66^{\mathrm{aA}}$ & $54^{\mathrm{aA}}$ \\
\hline $\mathrm{T} 4$ & $78^{\mathrm{aA}}$ & $76^{\mathrm{aA}}$ & $72^{\mathrm{aA}}$ & $66^{\mathrm{aA}}$ & $60^{\mathrm{aA}}$ & $54^{\mathrm{aA}}$ & $48^{\mathrm{aA}}$ \\
\hline
\end{tabular}

* Data is expressed as means

*Values followed by different upper case or lower case letters are significantly different $(\mathrm{p} \leq 0.05)$ within columns and rows respectively 
Table 5: Effect of storage period and treatments on \% Antioxidant activity of Bitter gourd juice

\begin{tabular}{|c|c|c|c|c|c|c|c|}
\hline Treatments & 0 & 1 & 2 & 3 & 4 & 5 & 6 \\
\hline $\mathrm{T} 1$ & $78.37^{\mathrm{aAB}}$ & $65.32^{\mathrm{bC}}$ & $56.18^{\mathrm{cC}}$ & $47.93^{\mathrm{dC}}$ & $39.22^{\mathrm{eC}}$ & $28.06^{\mathrm{fD}}$ & $18.17^{\mathrm{gD}}$ \\
\hline $\mathrm{T} 2$ & $75.89^{\mathrm{aB}}$ & $72.33^{\mathrm{abB}}$ & $68.43^{\mathrm{bcB}}$ & $62.56^{\mathrm{cB}}$ & $55.69^{\mathrm{dB}}$ & $46.22^{\mathrm{eC}}$ & $38.09^{\mathrm{fC}}$ \\
\hline $\mathrm{T} 3$ & $84.35^{\mathrm{aA}}$ & $83.06^{\mathrm{aA}}$ & $79.33^{\mathrm{abA}}$ & $75.26^{\mathrm{bcA}}$ & $70.47^{\mathrm{cdA}}$ & $65.63^{\mathrm{deA}}$ & $59.38^{\mathrm{eA}}$ \\
\hline $\mathrm{T} 4$ & $78.83^{\mathrm{aAB}}$ & $75.12^{\mathrm{aAB}}$ & $71.86^{\mathrm{bcAB}}$ & $66.77^{\mathrm{cdB}}$ & $60.39^{\mathrm{dB}}$ & $53.17^{\mathrm{eB}}$ & $45.73^{\mathrm{fB}}$ \\
\hline
\end{tabular}

* Data is expressed as means

*Values followed by different upper case or lower case letters are significantly different $(\mathrm{p} \leq 0.05)$ within columns and rows respectively 